\title{
ASSESSING HUMAN CAPITAL WITHIN THE NATIONAL WEALTH OF UKRAINE
}

ŚLĄSKI

PRZEGLĄD

STATYSTYCZNY

Nr 19(25)

ISSN 1644-6739

e-ISSN 2449-9765

\author{
Nataliya Lutchyn
}

Ivan Franko National University of Lviv

Department of Statistics

e-mail: nataliya.lutchyn@Inu.edu.ua

ORCID: 0000-0002-0727-0842

\begin{abstract}
(C) 2021 Nataliya Lutchyn
This work is licensed under the Creative Commons Attribution-ShareAlike 4.0 International License. To view a copy of this license, visit http://creativecommons.org/licenses/by-sa/4.0/

Quote as: Lutchyn, N. (2021). Assessing human capital within the national wealth of Ukraine. Śląski Przegląd Statystyczny, 19(25).
\end{abstract}

DOI: $10.15611 /$ sps.2021.19.03

JEL Classification: D12, C13, C25

\begin{abstract}
The study of the category of national wealth is necessary because the wealth of the nation is an important indicator of the economic power and potential of the country. However, today there are no equal views regarding the definition of the essence of national wealth. The aim of the article is to study the concept and structure of national wealth, the methods of its assessment, and most importantly - the ways to increase the national wealth of Ukraine. The main objective of this article is also to highlight the approaches of human capital measures and assessing its importance in the structure of national wealth. The article highlights the modern understanding of the essence and value of the category 'national wealth'. The evolution of the methodological approaches to assessing national wealth and determining its components is considered. The need to include human capital to the national wealth has been confirmed and substantiated. Bettering human capital benefits individuals and their country and leads to improved sustainability for the future.
\end{abstract}

Keywords: national wealth, human capital, produced capital, natural capital, analysis of variance.

\section{Introduction}

In the conditions of the strengthening globalization processes, the role of such a macroeconomic indicator as 'national wealth' plays an important role in the processes of sustainable development. The significance of national wealth is that it is a prerequisite for the subsequent cycles of the progressive growth of a national economy. The exacerbation of modern ecological, economic, demographic and resource-energy problems require a more detailed study of changes in the system of national wealth, the study of which is necessary because the wealth of a nation is an important indicator of its economic power and potential. However, there are certain 


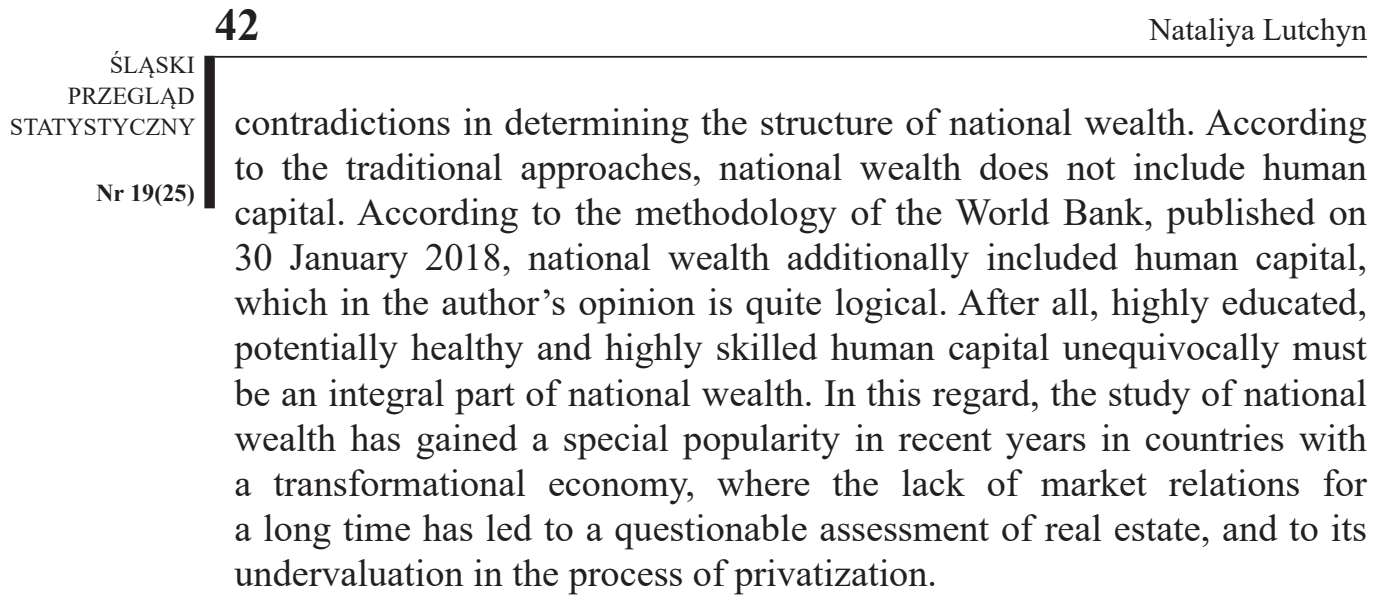

\section{Analysis of research problems}

The foundation of the modern understanding of the essence and meaning of the category 'national wealth' was laid in the classical political economy by W. Petty, A. Smith, and D. Ricardo. Historically, mercantilists (Ch. Davenant, T. Mann, W. Stafford in England, A. Montchretian in France) and physiocrats (F. Quesnay, V. Mirabeau, A. Turgot and others) were the first to scientifically study national wealth (Bobukh, 2011). The first economic assessment of a country's national wealth was the study by the English economist W. Petty, who divided wealth into components based on types of property. He calculated the value of its elements, based on various payback periods, taking into account the nature of their reproduction (Bobukh, 2011, p. 25).

The works by Lange (2004) and Guzev et al. (2020) are devoted to the modern problems of the assessment of national wealth. Human capital in the structure of national wealth was discussed only by Boarini et al. (2012), Pelinescu (2015), and Fraumeni (2021). This situation indicates the lack of attention to the problems of the analysis and importance of this element in national wealth.

Over the last ten years, an attempt to realistically assess the value of Ukraine's national wealth was presented in scientific studies by Lyakhovets (2009), Bobukh (2011), Kvak (2008), Shumska (2012), Stepanenko (2013) and monographs by Pyrozhkova and Khvesyk (2015). However, today there are no identical views defining the essence of national wealth. The ambiguity of interpretation of the concept and methods of its evaluation may indicate the lack of scientific developments in this field. In the calculations made in 2006 by World Bank experts, national wealth was considered as the current value of future consumption. Estimates of produced capital stocks were obtained on the basis of a continuous inventory model (Bobukh, 2011). According to the methodology of the World Bank, which was published 
on 30 January 2018, human capital was additionally included in national wealth. This is significantly different from past evaluations when general wealth was evaluated in another way, assuming that consumption is income STATYSTYCZNY from total wealth.

According to preliminary estimates, produced capital, natural capital and net foreign assets were calculated directly and then subtracted from the total property to obtain the balance. The balance, called 'non-material capital', was largely attributed to human capital. Nowadays, with the ability to directly measure human capital, total wealth can be estimated as the sum of each asset category.

\section{Statistical data and research method}

The calculation of such an important macroeconomic indicator as national wealth can be carried out on the basis of the System of National Accounts (SNA). The increase in wealth directly depends on the volume of production over a period of time.

To calculate the national wealth in the SNA, a balance of assets and liabilities is built, which completes the sequence of accounts in the system. The balance of assets and liabilities may consist of an institutional unit, sector, industries and the internal economy as a whole. For each sector, the balance sheet shows the financial assets and financial obligations adopted by the sector in order to attract financial resources. This information is important for identifying sectors that conduct net borrowing used to finance their deficit, as well as assets of sectors that carry out pure lending used to accommodate their surplus funds.

All types of economic assets are displayed in the balance sheet. By analogy with accumulation accounts, assets are displayed in the left side of the balance sheet, and liabilities and net value of capital in the right. The balancing article is the net value of equity, calculated as the difference between the value of all assets and the cost of liabilities. The net value of equity capital in the economy is generally the national wealth of the country, the volume of which is calculated in the cost expressed in market prices acting at the time of assessment (Shumska, 2012).

The World Bank data was also used to analyse the national wealth of Ukraine from 1995 to 2014.

Methods of structure analysis, analytical groupings and the analysis of variance were used in this study. One-factor analysis of variance was used in studies of changes in the volume of national wealth under the influence of changes of its components. 


\section{Results of analyses}

Nr 19(25) Using the experimental balances of non-financial and financial assets and liabilities for 2019, which were first presented on the website of the State Statistics Service of Ukraine in 2011 (Tables 1 and 2), one can obtain an estimate of national wealth.

Table 1. Experimental balance sheets of financial assets and liabilities in 2019, mln UAH

\begin{tabular}{|c|l|r|}
\hline \multicolumn{1}{|c|}{ Assets } & \multicolumn{1}{|c|}{ Indicator } & Liabilities \\
\hline 14294745 & Opening balance & 14975061 \\
\hline 762441 & Financial account & 839769 \\
\hline-562042 & $\begin{array}{l}\text { Other changes in financial assets and } \\
\text { liabilities account }\end{array}$ & -579992 \\
\hline 14495144 & Closing balance & 15234838 \\
\hline
\end{tabular}

Source: own study based on data from the State Statistics Service of Ukraine.

Table 2. Experimental balance of non-financial assets in 2019, mln UAH

\begin{tabular}{|l|c|c|c|c|}
\hline $\begin{array}{c}\text { Produced } \\
\text { non-financial assets* }\end{array}$ & Initial balance & $\begin{array}{c}\text { Capital } \\
\text { account }\end{array}$ & $\begin{array}{c}\text { Accounts } \\
\text { of other changes } \\
\text { in assets }\end{array}$ & $\begin{array}{c}\text { Final } \\
\text { balance }\end{array}$ \\
\hline Total & 15234838 & 15234838 & 15234838 & 15234838 \\
\hline Fixed assets* & 7424517 & $181389 * * *$ & 193249 & 7799155 \\
\hline $\begin{array}{l}\text { of which: } \\
\text { intellectual property } \\
\text { products }\end{array}$ & 66605 & -3173 & 22565 & 85997 \\
\hline Inventories & 1574936 & -109898 & 85353 & 1550391 \\
\hline
\end{tabular}

*Excluding values; **Excluding residential buildings related to the lack of detailed information on the quality of their composition and the market price; *** Net fixed capital formation.

Source: according to data from the State Statistics Service of Ukraine.

Table 3 shows the calculations of national wealth at the end of 2019.

Table 3. Balance of assets and liabilities at the end of 2019

\begin{tabular}{|l|c|l|r|}
\hline \multicolumn{1}{|c|}{ Assets } & mln UAH & \multicolumn{1}{|c|}{ Liabilities } & mln UAH \\
\hline 1. Non-financial assets & 9349546 & 3. Financial liabilities & 15234838 \\
\hline 2. Financial assets & 14495144 & $\begin{array}{l}\text { 4. Net value of equity (national } \\
\text { wealth) }\end{array}$ & 8609852 \\
\hline
\end{tabular}

Source: own study based on data from the State Statistics Service of Ukraine. 
Below are the dynamics of the net value of equity (national wealth) for 2013-2019 in actual and comparable prices (in 2013 prices).

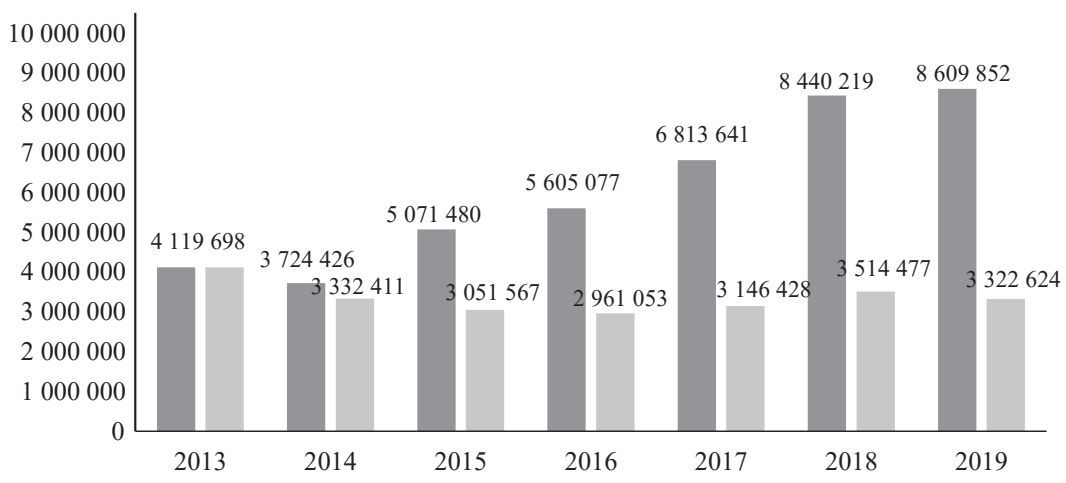

Net equity value at current prices $\quad$ Net equity value in comparable prices

Fig. 1. Dynamics of net value of equity (national wealth) for 2013-2019 in current and comparable prices, mln UAH

Source: own study.

Firstly, one can see a significant deviation between the indicators of the net value of Ukraine's equity in actual prices and in comparable prices, which indicates inflationary processes in the country with the simultaneous reduction of production volumes. However, the root cause of these processes is the political situation in the country and the significant loss of its territories - a sharp decline in net value of equity is observed for 2014 with a subsequent negative trend during 2015-2016. It was only in 2017, when the country's economy slightly recovered from the losses, that the tendency changed to growth.

The disadvantages of the methodology of calculating the national wealth of Ukraine within the framework of the SNA indicators are connected with the underestimation of natural capital and the lack of assessments of human capital. At present, when human capital ranks first among the factors of economic growth, ignoring the latter underestimates the potential of development.

Total human capital (according to the World Bank methodology) is calculated as the discounted value of income (the value of future income, estimated in the current conditions) of two groups: people aged 25 to 65 (expect to have graduated) and those aged 15-24, with a certain probability of going to school. Indicators such as annual earnings (by age, sex, level of education) and educational attainment (by age, sex) are taken from the 
International Income Distribution Base (I2D2). Years of schooling are taken from an updated assessment derived from I2D2. Population and mortality rate (by age, sex) were taken from the data of the United Nations Population Division and the share of labour in GDP (employed and selfemployed) from the UN national accounts (the World Bank).

Figure 2 shows the assessment of Ukraine's national wealth, according to the World Bank, during the period 1995-2014. The World Bank has not published any further calculations by countries.

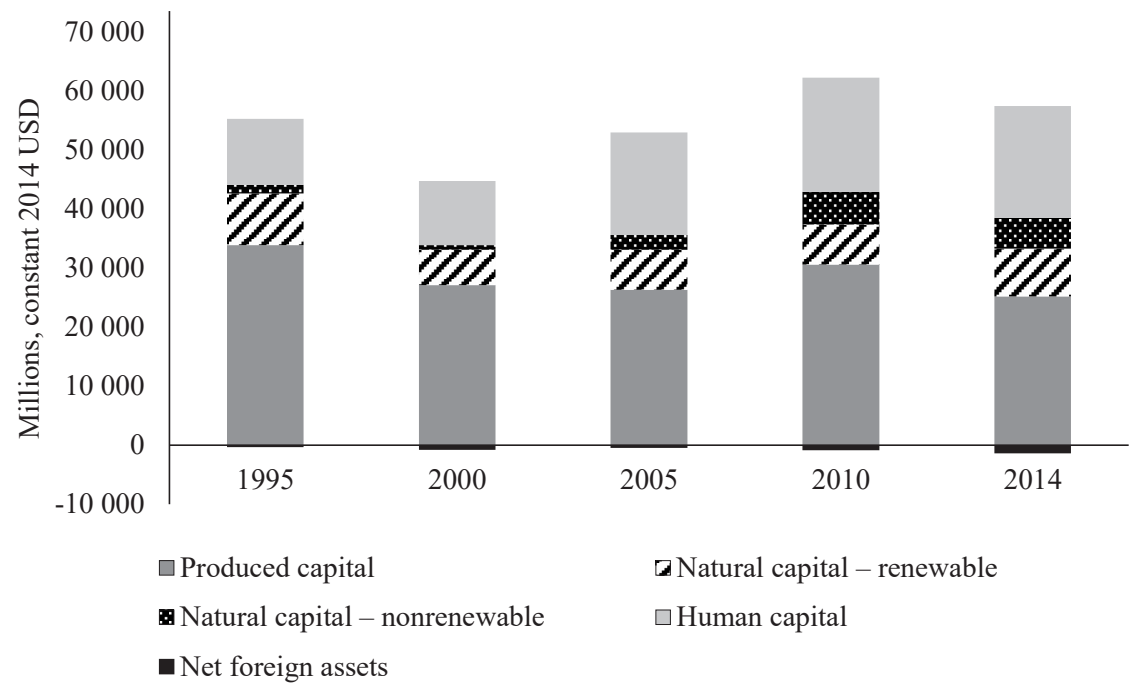

Fig. 2. Dynamics of components of national wealth of Ukraine during 1995-2014, mln USD Source: own study based on World Bank data.

As can be seen from Figure 2, after some growth there was a decrease in the national wealth of Ukraine in 2014. This situation is understandable and is related to the losses due to the annexation of Crimea and the formation of the disputed territories in Eastern Ukraine.

An attempt to calculate human capital according to the methodology of the World Bank and the data of the State Statistics Service of Ukraine was made. The components for this calculation are shown in Table 4.

Total human capital is calculated as the value of income (the value of future income, estimated in current conditions of 2018) for people aged 15-70.

Taking into account the international definition of those engaged in economic activities (employed population), the study considered people aged 15-70 (from 2019, aged 15 and older), who during the examined week: 
- worked at least 1 hour:

- by hiring, individually (independently), or at own (family) enterprise;

- self-employed, working in their own business or in a family farm;

- persons who were temporarily absent from work.

Table 4. Dynamics of human capital components for 2014-2019

\begin{tabular}{|l|r|r|r|r|r|r|}
\hline \multicolumn{1}{|c|}{ Indexes } & 2014 & 2015 & 2016 & 2017 & 2018 & 2019 \\
\hline $\begin{array}{l}\text { Disposable income } \\
\text { per capita, UAH }\end{array}$ & 21442.8 & 17768.9 & 18431.6 & 20665.6 & 23057.1 & 57909.2 \\
\hline Population, thousand & 45426.2 & 42929.3 & 42760.5 & 42584.5 & 42386.4 & 41858.2 \\
\hline $\begin{array}{l}\text { Employed population } \\
\text { aged 15-70 years, } \\
\text { thousand }\end{array}$ & 18073.3 & 16443.2 & 16276.9 & 16156.4 & 16360.9 & 16578.3 \\
\hline $\begin{array}{l}\text { Number of students } \\
\text { in higher education } \\
\text { institutions per } \\
10000 \text { inhabitants }\end{array}$ & 393 & 375 & 373 & 363 & 361 & 299 \\
\hline
\end{tabular}

Source: own study based on data from the State Statistics Service of Ukraine.

The formula below calculates for how many years the employed population aged 15-70 will work and, consequently, generate income

$$
\text { Years }=\sum_{n=15}^{n=70}(70-n)=1540 .
$$

The mortality rate at the age of $15-70$ is $18 \%$, so the number of years was reduced by $18 \%$ to obtain 1262.8 . This indicator was multiplied by the number of employed populations aged 15-70 and the disposable income per capita in 2018. In order to compare it with human capital, as calculated by the World Bank, the author converted UAH to USD in 2018, which amounted to 26.6 .

The calculated indicator of human capital in 2018 was 17897307.8 million USD, thus the human capital of Ukraine after a significant decrease in 2014 partially increased over those 4 years. Obviously, this assessment is not sufficiently accurate, taking into account the lack of information about the years under study. However, in the author's opinion, the growth of human capital still took place.

Next the distribution of components of national wealth and whether there is a regularity was analysed using analysis of variance. When performing analysis of variance, it is necessary to check the normality of the distribution of the studied random variable and the absence of differences in the variances of the populations (Rudenko, 2012). 
The analysis was based on World Bank data for 16 countries.

Nr 19(25) Table 5. Analytical grouping of European countries by components of national wealth, USD

\begin{tabular}{|l|c|c|c|}
\hline \multirow{2}{*}{ Country } & \multicolumn{3}{|c|}{ National wealth (Per Capita), USD } \\
\cline { 2 - 4 } & Produced capital & Natural capital & Human capital \\
\hline Belgium & 211872.7 & 5012.8 & 404997.3 \\
\hline France & 223830.1 & 11108.6 & 415850.9 \\
\hline United Kingdom & 193455.7 & 7592.0 & 457222.7 \\
\hline Spain & 142820.5 & 10298.2 & 215592.8 \\
\hline Italy & 188054.7 & 8619.3 & 241349.6 \\
\hline Malta & 75153.5 & 1654.8 & 218865.3 \\
\hline Greece & 134895.0 & 12546.2 & 105662.8 \\
\hline Germany & 236890.7 & 7700.6 & 467668.1 \\
\hline Netherlands & 234414.6 & 9528.3 & 516543.5 \\
\hline Estonia & 91645.8 & 20092.8 & 155040.7 \\
\hline Ukraine & 25170.5 & 13345.2 & 18952.1 \\
\hline Lithuania & 63254.2 & 12757.7 & 100081.4 \\
\hline Bulgaria & 23185.5 & 16683.5 & 47592.8 \\
\hline Hungary & 65561.0 & 6622.6 & 102557.4 \\
\hline Moldova & 14212.8 & 4897.5 & 17852.4 \\
\hline Belorussia & 33388.2 & 21881.7 & 49003.6 \\
\hline Austria & 256743.9 & 16265.5 & 421845.7 \\
\hline Portugal & 117409.3 & 9189.4 & 172162.5 \\
\hline Poland & 285791.5 & 27890.2 & 576520.6 \\
\hline & & & \\
\hline
\end{tabular}

Source: own study based on World Bank data.

The first step was to formulate the hypotheses by the one-factor analysis of variance:

$H_{0}$ : There is no difference in the average indicators of the components of national wealth (produced capital, natural capital, human capital), for different countries they have different shares in the total wealth.

$H_{1}$ : There is a difference in the components of national wealth (produced capital, natural capital, human capital).

Table 6 shows the results for the generated samples. 
Table 6. Results of analysis of variance for one-factor experiments

\begin{tabular}{|l|c|r|r|r|}
\hline \multicolumn{1}{|c|}{ Groups } & \multicolumn{1}{c|}{ Score } & \multicolumn{1}{c|}{ Sum } & \multicolumn{1}{c|}{ Average } & \multicolumn{1}{c|}{ Variance } \\
\hline Produced capital & 19 & 2617750.2 & 137776.3 & 7943931559.0 \\
\hline Natural capital & 19 & 223686.8 & 11773.0 & 42206876.9 \\
\hline Human capital & 19 & 4705362.2 & 247650.6 & 34440808577.1 \\
\hline
\end{tabular}

Source: own study.

Table 7 shows the results of the analysis of variance.

Table 7. Results of the analysis of variance

\begin{tabular}{|l|c|c|c|c|c|c|}
\hline \multicolumn{7}{|c|}{ Dispersion analysis } \\
\hline $\begin{array}{c}\text { Source } \\
\text { of variation }\end{array}$ & SS & df & MS & F & P-value & $\begin{array}{c}\text { F } \\
\text { critical }\end{array}$ \\
\hline $\begin{array}{l}\text { Between } \\
\text { groups }\end{array}$ & 792596491332.4 & 2 & 264198830444.1 & 24.7722 & $4.05 \mathrm{E}-11$ & 2.7318 \\
\hline $\begin{array}{l}\text { Within } \\
\text { groups }\end{array}$ & 767887621145.1 & 54 & 10665105849.2 & & & \\
\hline Total & 1560484112477 & 56 & & & & \\
\hline
\end{tabular}

Source: own study according to Table 4.

Next the study checked the correlation for density by means of $\eta^{2}$

$$
\eta^{2}=\frac{\text { SSB }}{\text { SST }}=\frac{792596491332.4}{1560484112477.5}=0.5079 .
$$

The Chedok scale is used to describe the conclusions about the significance of the correlation (Table 8).

Table 8. The Chedok scale

\begin{tabular}{|c|c|c|c|c|c|}
\hline Level & $0.1-0.3$ & $0.3-0.5$ & $0.5-0.7$ & $0.7-0.9$ & $0.9-1.0$ \\
\hline Characteristics & weak & moderate & medium & high & very high \\
\hline
\end{tabular}

Source: (Rudenko, 2012).

In this case, with a value of 0.5079 , one can say that there is an average relation.

Let us check the significance of the correlation using Fisher's F-test:

$$
F=\frac{\frac{S S B}{k-1}}{\frac{S S W}{n-k}}=24,7722 .
$$


To check the level of significance, it was necessary to determine the critical value of the $\mathrm{F}$ distribution for the degrees of freedom: $d f=k-1=2$ and $d f=n-k=54$.

From the tabulated values F-critical $=2,7318$.

Therefore, since $\mathrm{F}$ fact $>\mathrm{F}$ critical, one rejects the null hypothesis and with a probability of $95 \%$ confirms that the average values are different and there are significant differences in the average values of the components of national wealth.

Thus, one can confirm the statistical significance of the differences between the averages of random variables in groups, corresponding to different components of national wealth. Table 9 shows that the largest contribution to national wealth was made by human capital.

Table 9. Share of components of national wealth, 2014

\begin{tabular}{|l|c|c|c|}
\hline \multirow{2}{*}{ Country } & \multicolumn{3}{|c|}{ Share of components of national wealth, 2014 } \\
\cline { 2 - 4 } & Produced capital & Natural capital & Human capital \\
\hline Belgium & 33 & 1 & 63 \\
\hline France & 35 & 2 & 65 \\
\hline United Kingdom & 30 & 1 & 71 \\
\hline Spain & 42 & 3 & 63 \\
\hline Italy & 44 & 2 & 56 \\
\hline Malta & 25 & 1 & 72 \\
\hline Greece & 59 & 6 & 46 \\
\hline Germany & 32 & 1 & 64 \\
\hline Netherlands & 30 & 1 & 65 \\
\hline Estonia & 35 & 8 & 60 \\
\hline Ukraine & 45 & 24 & 34 \\
\hline Lithuania & 37 & 8 & 59 \\
\hline Bulgaria & 28 & 20 & 62 \\
\hline Hungary & 40 & 14 & 50 \\
\hline Moldova & 40 & 22 & 49 \\
\hline Belorussia & 33 & 2 & 61 \\
\hline Austria & 37 & 7 & 63 \\
\hline Portugal & 43 & & 73 \\
\hline Poland & 26 & 3 & \\
\hline
\end{tabular}

Source: own study based on World Bank data.

Hence one can confirm the regularity in the distribution of components of national wealth.

Therefore, human capital is a key factor for the process of growth and competitiveness (Abdelmajied and Safijllin, 2018). This, taking an example 
from highly developed countries, Ukraine should prioritise investment in human capital. The investment in human capital growth guarantees further economic development for the country.

\section{Conclusions}

National wealth is an important indicators of economic development. It is a set of material goods, created in the country and accumulated by the work of the entire society, its level of education, production experience, skills, and the creative talent of the population.

Today in Ukraine there is no methodology of valuations, and systematic research of national wealth. Such methodology would give an opportunity to assess the actual loss of national wealth as a result of the annexation of Crimea and the formation of the disputed territories as a result of the hostilities in Eastern Ukraine.

The qualitative and systematic analysis of the study of the national wealth of Ukraine is necessary in order to outline ways to improve the efficiency of its use. Determining the composition and state of the national wealth of the country allows to identify the main priorities of development, i.e. to formulate and adjust structural policy, privatization policy, investment policy etc.

According to the results of the analysis, it can be concluded that in Ukraine the priority area for the growth of national wealth is investment in human capital. Improvement in human capital leads to improved sustainability for the future.

In further research, taking into account the global situation, it is necessary to analyse the impact of COVID-19 on the structure and dynamics of human capital.

\section{References}

Abdelmajied, F., and Safijllin, L. (2018). Approaches for measuring human capital and its effect on economic growth in (MENA) region: A panel data analysis. Retrieved from https://www.researchgate.net/publication/330343961

Bobukh, I. M. (2011). Otsinka natsionalnogo baghatstva u konteksti mizhnarodnogo dosvidu. Ekonomika i prognozuvannya, 10(24-39).

Boarini, R., Mira d'Ercole, M., and Liu, G. (2012). Approaches to measuring the stock of human capital: A review of country practices. OECD Statistics WP, (04/2012). Retrieved from https://www.researchgate.net/deref/

Database of the State Statistics Service of Ukraine. (n.d.). Retrieved from http://www. ukrstat.gov.ua/

Fraumeni, B. M. (Ed.). (2021). Measuring human capital. Academic Press, an imprint of Elsevier. 
Guzev, M. M., Ledeneva, M. V., and Polkovnikov, A. A. (2020). National wealth structure of the countries of the world, 2000-2014, and economic development. Applied Econometrics and International Development, 20(2), 33-49.

Ignatieva, M. N., Yurak, V. V., and Logvinenko, O. A. (2021). Natural capital. approaches to economic assessment. Eurasian Mining, 35(1), 39-44. doi:10.17580/em.2021.01.08

Kvak, M. V.(2008). Natsionalne bagatstvo v systemi formuvannya ekologhichno zbalansovanogo rozvytku ekonomiky Ukrayiny. Aktualni problem rozvytku ekonomiky region, IV(2), 257-264.

Lange, G. (2004). Wealth, natural capital, and sustainable development: Contrasting examples from Botswana and Namibia. Environmental and Resource Economics, 29(3), 257-283. doi:10.1007/s10640-004-4045-Z

Lyakhovets, O. O. (2009). Otsinka natsionalnogo bagatstva Ukrainy. Ekonomika - Economy. Scientific Works, 126(113), 5-10.

Pelinescu, E. (2015). The impact of human capital on economic growth (2nd International Conference "Economic Scientific Research - Theoretical, Empirical and Practical Approaches", 13-14 November 2014, Bucharest Procedia Economics and Finance, Romania, No. 22, pp. 184-190). Retrieved from https://www.researchgate.net/

Pyrozhkova, S. I., and Khvesyk M. A. (Eds.). (2015). Ekonomichna ocinka pryrodnogho baghatstva Ukrajiny. Kyjiv: DU IEPSR NAN of Ukraine.

Rudenko, V. M. (2012). Matematychna statystyka. Tutorial. Kyiv: Tsentr uchbovoyi literatury.

Shumska, S. S. (2012). Natsionalne bagatstvo Ukrainy u vymiri pokaznykiv SNR. Finansy Ukrainy, (4), 27-40.

Stepanenko, S. V. (2013). Pidvyshennya efektyvnosti protsesiv suspilnogo vidtvorennya ta vykorystannya natsionalnogo bagatstva. Teoriya ta praktyka derzhavnogo upravlinnya, 3(42), 81-88.

The Changing Wealth Of Nations. (2018). International Bank for reconstruction and development. The World Bank. Retrieved from http://www.worldbank.org

The World Bank. (n.d.). The changing wealth of nations. Retrieved from http://www.documents.worldbank.org/curated/en/630181468339656734/

\section{OCENA KAPITALU LUDZKIEGO W BOGACTWIE NARODOWYM UKRAINY}

Streszczenie: Badanie kategorii bogactwa narodowego jest konieczne, ponieważ jest ono ważnym wskaźnikiem siły i potencjału gospodarczego kraju. Celem artykułu jest poznanie pojęcia i struktury bogactwa narodowego, metod jego oceny, a przede wszystkim sposobów zwiększania bogactwa narodowego Ukrainy. Głównym zadaniem opracowania jest także zwrócenie uwagi na podejście do pomiaru kapitału ludzkiego oraz ocena jego znaczenia w strukturze bogactwa narodowego. Zwrócono uwagę na współczesne rozumienie istoty i znaczenia kategorii „bogactwo narodowe”. Prowadzono również rozważania na temat ewolucji podejść metodologicznych do oceny bogactwa narodowego i określania jego składowych. Potrzeba włączenia kapitału ludzkiego do bogactwa narodowego została potwierdzona i uzasadniona. Poprawa kapitału ludzkiego przynosi korzyści jednostkom i ich krajom oraz prowadzi do lepszego zrównoważenia na przyszłość.

Słowa kluczowe: bogactwo narodowe, kapitał ludzki, wytwarzany kapitał, kapitał naturalny, analiza wariancji. 